\title{
Nota de abertura
}

Entre 2013 e 2018, o Instituto de Literatura Comparada Margarida Losa organizou uma série de Seminários do Fim do Mundo. Durante vinte e quatro sessões, falou-se sobre a representação e o imaginário da catástrofe, o cancelamento do tempo, a ruína das civilizações, o desaparecimento da existência humana; convocaram-se perspectivas artísticas, filosóficas, teológicas, políticas; interrogaram-se poemas, filmes, bandas desenhadas, videojogos. Após um ano de intervalo (ou um descanso sabático...), urgia regressar a todas essas questões - para pensar o seu reverso.

Se a História humana regista tantas formas de destruição e esquecimento, se o fim é uma ameaça insistente e plural, de que modo(s), pelo contrário, se pode salvar o mundo? Que palavras, gestos e acções permitem enfrentar a catástrofe e o aniquilamento? Como podem as artes inventar modelos de resistência, resgatar memórias, inaugurar um novo universo? E, finalmente: por que razão deve o mundo ser salvo? Para tentar responder, o Instituto de Literatura Comparada Margarida Losa organiza, desde Novembro de 2020 (em plena segunda vaga da pandemia de Covid-19), os Seminários da Salvação do Mundo, realizados on-line e transmitidos pelo youtube. Os libretos Materiais para a Salvação do Mundo publicam textos resultantes desses seminários abertos, ou tematicamente afins.

Neste volume, Sofia Miguens revisita o pensamento de Walter Benjamin sobre a arte como salvação. Contra modelos da História como progresso ou decadência, pensa-se o tempo enquanto objecto de rememoração do artista; uma rememoração que realiza finalmente o tempo pretérito: "Construir a história é uma forma de realizar o passado”, talvez de o salvar. Rememorando a história do Brasil, Luca Argel revê séculos de conflitos, a história da escravatura, o genocídio de povos autóctones: "Como sobreviveram os nativos americanos e os africanos ao fim dos seus mundos?" Neste país que "não é para principiantes”, uma resposta pode ser o samba, forma depurada de protesto e resistência. A mesma resistência talvez defina também a literatura: no ensaio de Maria Beatriz Almeida, reconhecem-se os limites da escrita num universo de crises ecológicas e humanitárias, mas para concluir que os poemas ao menos ajudam a recordar "o que nos mantém longe da utopia” - e, através desse frágil protesto, convidam a salvar o mundo.

Pedro Eiras 